\title{
The Dynamic Impact of Renewable Energy Consumption on Economic Growth: The Case of Côte d'Ivoire
}

\author{
Jeffrey Kouton* Sulpice Amonle \\ Ecole Nationale Supérieure de Statistique et d'Economie Appliquée, Abidjan, Côte d'Ivoire
}

\begin{abstract}
This paper investigates the impact of renewable energy consumption on economic growth in Côte d'Ivoire by using the autoregressive distributed lags (ARDL) model. Capital and labor are included in the model as additional variables. Annual data cover the period from 1991 to 2015. The empirical results suggest that in the short run, the impact of renewable energy consumption on economic growth is mixed while in the long run, the impact is not significant. Our results also provide empirical evidence that the non-renewable energy/renewable energy transition is not yet effective but is under process in Côte d'Ivoire.
\end{abstract}

Keywords: Economic growth, Renewable energy consumption, Côte d'Ivoire

DOI: $10.7176 / \mathrm{JESD} / 10-18-20$

Publication date:September $30^{\text {th }} 2019$

\section{Introduction}

Over the recent years, most of countries has been looking for new development models. This includes looking for inclusive growth and sustainable development, preserving environment while generating high level of economic growth that is created by and benefits to all the segments of population.

With respect to sustainable development, tremendous progress has been made since the successive implementation of the Millennium Development Goals (MDGs) and the Sustainable Development Goals (SDGs). The SDGs emphasize the role of affordable, sustainable, clean and renewable energy in attaining sustainable development. First, this is because fuel-based energy sources, known as non-renewable energy, are the main sources of energy that are still being used by the majority of countries. Yet, this type of energy harms environment by generating considerable quantity of carbon emissions. Second, since 1990, there is a rapid evolution of the number of people that have access to and demand electricity. Third, there is a high potential of renewable energy worldwide. With a specific view to the African continent, the Hermann et al. (2014) estimates show that the total theoretical renewable energy potentials in Africa are estimated at approximatively 470 Petawatt hours (PWh) for concentrating solar power, $660 \mathrm{PWh}$ for photovoltaics and $460 \mathrm{PWh}$ for wind.

In Côte d'Ivoire, renewable energy has been recognized at the institutional level as critical regarding its role for development, leading to commitments and strategies for their promotion. The country has a national action plan for renewable energy and recently committed to increase the share of renewable energy in the total energy mix to $42 \%$ by 2030 . Moreover, financiers' commitments increased in favor of the country. In September 2017, the African Development Bank approved a 50 million Euros financing for an hydroelectric power project in Singrobo-Ahouaty in the center region of Côte d'Ivoire. The country currently encounters an increase demand in energy and low electrification. Furthermore, energy consumption generated by economic growth contributes to environmental degradation in Côte d'Ivoire (Esso and Keho, 2016). The authors suggested that the country should explore policies aiming at reducing carbon emissions. Hence it appears important to increase energy supply by diversifying the sources of energy generation, meet the increasing demand and preserve environment.

Esso (2010) found that energy consumption is determinant in Côte d'Ivoire's economic growth process and suggested the country to seek for improving renewable energy generation in order to increase the global energy supply. According to Kouakou (2011) who studied the relationship between electricity consumption and economic growth in Côte d'Ivoire, it is important to secure the long-run supply of energy in order to achieve a sustainable economic growth. The total energy installed capacity of the country stands at 1450 Mega-Watts (MW) in 2011, $1886 \mathrm{MW}$ in 2016 and the country aims to attain a capacity of 2000MW by 2020 by valuing renewable energy.

An analysis of the context of energy in Côte d'Ivoire suggests that the country's energy resources mainly include fossil fuel ( $68 \%$ of the total installed capacity in 2016) and hydropower energy ( $32 \%$ of the total installed capacity in 2016). Biomass energy is quite well developed and is a common source of energy used mainly by rural populations. Wind energy and biogas technology are also available but are not fully exploited. Solar energy is abundant in the country especially in the northern region which has the highest rate of solar radiation. Koua et al. (2015) presented a nice and exhaustive view of the potential of renewable energy in Côte d'Ivoire. The authors pointed out that renewable energy has both technical and socio-economic viability in Côte d'Ivoire. The main reasons advocated are: the high cost of electricity, economy oil-based and abundance of renewable energy sources. The author emphasized the need of conducting more studies in the renewable energy field in Côte d'Ivoire.

The aim of this study is to empirically examine the dynamic impact of renewable energy consumption on economic growth in Côte d'Ivoire. The study of the dynamics between the two variables is justified by the desire 
to capture the effects of the non-renewable energy / renewable energy transition on economic growth, which corresponds to a short-run dynamic. In addition, a long-run analysis will explore the possible existence of a longrun relationship between renewable energy consumption and economic growth in Côte d'Ivoire. The dynamic relationship is assessed using the Autoregressive Distributed Lags (ARDL) approach of Pesaran et al. (2001) which allows to estimate both short and long-runs dynamics. The study extends the existing literature on the dynamic relationship between renewable energy consumption and economic growth to the specific case of Côte d'Ivoire. In the literature there is, to the best of our knowledge, no empirical study devoted to such analysis.

This paper is divided into five parts. After the introduction, Section two presents a brief literature review. Section three presents the data and the methodology. Section four presents and discusses the empirical findings while Section five concludes and provides policy recommendations.

\section{Brief literature review}

The relationship between renewable energy consumption and economic growth has driven considerable amounts of research papers over the years. These studies are conducted either on panel data framework or by considering country-specific cases. This section presents a brief review of some of the recent studies that focus on countryspecific cases.

Shahbaz et al. (2015) supported the existence of a long-run relationship between renewable energy consumption and economic growth in Pakistan. Alper and Oguz (2016) explored the causal nexus between renewable energy consumption and economic growth for some European Union countries from 1990 to 2009. Using the ARDL approach, their results revealed evidence in favor of a positive impact of renewable energy consumption on economic growth. However, this impact is not statistically significant for all the countries. The significant positive impact was only found for Bulgaria, Estonia, Poland, and Slovenia. Moreover, no causality evidence was found for Cyprus, Estonia, Hungary, Poland and Slovenia. Aslan (2016), using the ARDL approach, provided evidence of a positive effect of biomass energy consumption on economic growth in the United States in both short and long runs. Futhermore, applying the Toda-Yamamoto causality test, he found a unidirectional causality running from biomass consumption to economic growth. Following Aslan (2016), Bildirici and Ôzaksoy (2016) showed that there is a unidirectional causality running from woody biomass energy consumption to economic growth in Angola, Guinea-Bissau and Niger. The results also revealed a causality from economic growth to woody biomass energy consumption in Seychelles and a bidirectional relationship between biomass energy consumption and economic growth in Benin, Mauritania, Nigeria and South Africa.

Applying the ARDL approach, Amri (2017) found that non-renewable energy enhance economic growth in Algeria and that there is a long-run unidirectional causality from renewable energy to economic growth. The author also established a short-run causality running from non-renewable energy to renewable energy.

Ohlan (2016) supported the absence of an impact of renewable energy on economic growth in India in the long run. The causality analysis he implemented however suggested that in the short run, there is a unidirectional causality from renewable energy consumption to economic growth. Solarin and Ozturk (2015) concluded that there is a long-run unidirectional causality running from hydroelectricity consumption to economic growth in Brazil, Chile, Colombia, Ecuador and Peru. Their results also suggested that there is a long-run bidirectional causality between hydroelectricity consumption and economic growth for Argentina and Venezuela. Conversely, in the short run, the authors failed to find a causality mechanism between the variables.

Yazdi and Shakouri (2017) applied the ARDL model over the period 1979-2014 to investigate the relationship between renewable energy consumption and economic growth in Iran. They found that renewable energy consumption negatively affects economic growth in both short and long run. A similar result has been found by Ocal and Aslan (2013) for the case of Turkey. Yazdi and Shakouri (2017) concluded, based on a granger causality approach, the presence of a unidirectional causal relationship from renewable energy consumption to economic growth. On the contrary, Ocal and Aslan (2013) found that in Turkey, the unidirectional causal relationship runs from economic growth to renewable energy consumption. Bhattacharya et al. (2016) explored and found that renewable energy consumption decreases economic growth in India, Ukraine, Israel and the U.S. The study suggested these countries to keep using non-renewable energy.

Country-specific studies on the relationship between energy consumption and economic growth in Côte d'Ivoire include Keho (2007), Esso (2010) and Kouakou (2011). To date, to the best of our knowledge, there is no empirical study which investigated the relationship between renewable energy consumption and economic growth for the country-specific case of Côte d'Ivoire. Hence, we attempt to fill this gap in the literature.

\section{Data and methodology}

In order to be consistent with the literature, the study relies on a neoclassical framework which extends the relationship between renewable energy consumption and economic growth by including capital and labor (Lean and Smith, 2010; Ocal and Aslan, 2013; Solarin and Ozturk, 2015; Aslan, 2016). Annual data covering the period 1991-2015 were obtained from the SE4ALL (Sustainable Energy for all) database and the World Development 
Indicators (WDI) database. Precisely, real Gross Domestic Product (GDP), labor force and capital stock are drawn from the WDI while renewable energy consumption comes from the SE4ALL. The model functional form is formulated as follows:

$Y_{t}=f\left(R E N_{t}, L A B_{t}, C A P_{t}\right)$

Where $t=1, \ldots, T$ is the time period. $Y$ refers to economic growth measured by the real GDP (Constant 2010 US $\$$ ); REN denotes renewable energy consumption from all renewable resources (hydro, solid biofuels, wind, solar, liquid biofuels, biogas, geothermal, marine and waste) and is expressed in Tera-Joule (TJ). LAB denotes the labor force (in millions); CAP is the capital stock measured by the gross fixed capital formation (\% GDP). All the variables are taken into the natural logarithm and the function presented in (1) is developed as follows:

$\ln \left(Y_{t}\right)=\alpha_{0}+\alpha_{1} \ln \left(R E N_{t}\right)+\alpha_{2} \ln \left(L A B_{t}\right)+\alpha_{3} \ln \left(C A P_{t}\right)+\mu_{t}$

Where $\mu_{t}$ is the idiosyncratic term.

Consequently to the model specification, we use the following steps in the empirical framework of the paper. First, we check the stationarity of the variables by conducting unit root tests. Specifically, the study applies unit root tests that account for structural breaks in the series. This choice is made because Côte d'Ivoire experimented in the period under study several political and socio-economic crisis which may have affected the behavior of the variables. The Zivot and Andrews (1992) and the Clemente et al. (1998) unit root tests are applied. Both tests consider structural breaks as unknown and search for them endogenously. The main difference between the two tests is that Zivot and Andrews (1992) determine one break whereas Clemente et al. (1998) determine two breaks. In fact, several breaks can occurs in the evolution of the series and in this case, the Zivot and Andrews (1992) test will not be able to detect them all. The null hypothesis of the Zivot and Andrews (1992) test is the presence of unit root with structural break. If the t-statistic is greater than the critical value, then the null hypothesis cannot be rejected. It is worth mentioning that the structural break can be in the intercept, in the trend or in both intercept and trend. The Clemente et al. (1998) test relies on the null hypothesis of unit root. If the t-statistics is smaller in absolute terms than the critical value then the null hypothesis cannot be rejected. The test is based on an additive outliers model which is used to generate the unexpected and brutal changes in the mean of the variables. Moreover, an innovational outliers model can be used to find out gradual and soft changes in the mean of the variables.

Second, the ARDL bound testing approach initiated by Pesaran et al. (2001) is used to test for cointegration and to estimate the short and long runs effects of renewable energy consumption on economic growth. This method is used because it offers several advantages: (1) The ARDL approach to cointegration provides more efficiency than a number of existing cointegration tests namely Engle and Granger (1987), Johansen (1988) and Johansen and Juselius (1990); (2) The ARDL approach can be applied irrespective to the fact that the series are integrated of order one or are stationary; (3) The ARDL approach corrects the autocorrelation in the residuals and solves any potential endogeneity issue among the variables (Pesaran and Shin, 1999). In fact, in the same way that renewable energy consumption affects economic growth, economic growth could also affect renewable energy consumption (Apergis and Payne, 2011; da Silva et al., 2018); (4) The method allows to simultaneously estimate the short and long-runs dynamics; (5) It can be used even in the case of small sample size (as in the case of this study) as it provides unbiased and consistent estimators for the long-run relationship.

The procedure of Pesaran et al. (2001) can be implemented in two main steps. In the first stage, cointegration is tested among the series. Hence, for the bounds testing approach, the following model is estimated:

$\Delta \mathrm{Y}_{\mathrm{t}}=\alpha_{0}+\sum_{\mathrm{i}=1}^{\mathrm{m}} \beta_{1 \mathrm{i}} \Delta \mathrm{Y}_{\mathrm{t}-\mathrm{i}}+\sum_{\mathrm{i}=0}^{\mathrm{n}} \gamma_{1 \mathrm{i}} \Delta R E N_{\mathrm{t}-\mathrm{i}}+\sum_{\mathrm{i}=0}^{\mathrm{p}} \delta_{1 \mathrm{i}} \Delta \mathrm{LAB}_{\mathrm{t}-\mathrm{i}}+\sum_{\mathrm{i}=0}^{\mathrm{q}} \theta_{1 \mathrm{i}} \Delta \mathrm{CAP}_{\mathrm{t}-\mathrm{i}}+\varphi_{1} \mathrm{Y}_{\mathrm{t}-1}+\varphi_{2} \mathrm{REN}_{\mathrm{t}-1}+$ $\varphi_{3} \mathrm{LAB}_{\mathrm{t}-1}+\varphi_{4} \mathrm{CAP}_{\mathrm{t}-1}+\varepsilon_{\mathrm{t}}(3)$

$\Delta$ is the difference operator, $\varepsilon_{\mathrm{t}}$ is the error term and assumed to be independently and identically distributed. The letters $m, n, p$ and $q$ stand for the lag lengths. The Akaike Information Criteria is used to select the optimal lags, which may be different from a variable to another one.

Testing for cointegration requires to compute an F-statistic which is then compared to two critical values. The first critical value, the lower bound, supposes that all the variables are stationary at level. The second critical value, the upper bound, supposes all the variables be integrated of order one. If the F-statistic is less than the lower bound of the critical values then the null hypothesis of no cointegration $\left(\varphi_{1}=\varphi_{2}=\varphi_{3}=\varphi_{4}=0\right)$ cannot be rejected. Conversely, if the F-statistic is higher than the upper bound, there is cointegration between the variables. In such case, the second stage is to derive an Autoregressive Distributed Lags-Error Correction Model (ARDL-ECM) from the equation (3) above. The ARDL-ECM is written as below:

$\Delta \mathrm{Y}_{\mathrm{t}}=\alpha_{0}+\sum_{\mathrm{i}=1}^{\mathrm{m}} \beta_{1 \mathrm{i}} \Delta \mathrm{Y}_{\mathrm{t}-\mathrm{i}}+\sum_{\mathrm{i}=0}^{\mathrm{n}} \gamma_{1 \mathrm{i}} \Delta R E N_{\mathrm{t}-\mathrm{i}}+\sum_{\mathrm{i}=0}^{\mathrm{p}} \delta_{1 \mathrm{i}} \Delta \mathrm{LAB}_{\mathrm{t}-\mathrm{i}}+\sum_{\mathrm{i}=0}^{\mathrm{q}} \theta_{1 \mathrm{i}} \Delta \mathrm{CAP}_{\mathrm{t}-\mathrm{i}}+\varphi \mathrm{ECT}_{\mathrm{t}-1}+\varepsilon_{\mathrm{t}}$ Where $\mathrm{EC}_{\mathrm{t}-1}$ is the one-period lagged error correction term and $\varphi$ is the speed of adjustment parameter

\section{Empirical results and discussion}

4.1. Unit root tests

Table 1 first reports the results of the Zivot and Andrews (1992) unit root test. The test is conducted by considering three different models: a model with break in the intercept, a model with break in the trend and a model with break 
in both trend and intercept. On the one hand, real GDP, renewable energy consumption and capital appear to exhibit unit root with structural breaks. Indeed, the t-statistic is greater than the $5 \%$ critical value for any of the model specification chosen. On the other hand, labor force is stationary at level as the t-statistic is less than the $5 \%$ critical value.

Table 1: Zivot and Andrews' (1992) unit root test results

\begin{tabular}{|c|c|c|c|c|c|c|c|c|c|c|c|c|}
\hline \multirow[t]{2}{*}{$\begin{array}{l}\text { Variabl } \\
\text { es }\end{array}$} & \multicolumn{4}{|c|}{ Model A: Break in Intercept } & \multicolumn{4}{|c|}{ Model B: Break in Trend } & \multicolumn{4}{|c|}{$\begin{array}{c}\text { Model C: Break in both Trend and } \\
\text { Intercept }\end{array}$} \\
\hline & $\begin{array}{c}\text { Bre } \\
\text { ak }\end{array}$ & $\begin{array}{c}\mathrm{La} \\
\mathrm{g}\end{array}$ & $\begin{array}{l}\text { Min. t- } \\
\text { stat }\end{array}$ & $\begin{array}{c}5 \% \\
\text { critic } \\
\text { al } \\
\text { valu } \\
\text { e }\end{array}$ & $\begin{array}{c}\text { Bre } \\
\text { ak }\end{array}$ & $\begin{array}{c}\mathrm{La} \\
\mathrm{g}\end{array}$ & $\begin{array}{l}\text { Min. t- } \\
\text { stat }\end{array}$ & $\begin{array}{c}5 \% \\
\text { critic } \\
\text { al } \\
\text { valu } \\
\text { e }\end{array}$ & Break & Lag & $\begin{array}{l}\text { Min. t- } \\
\text { stat }\end{array}$ & $\begin{array}{c}5 \% \\
\text { critical } \\
\text { value }\end{array}$ \\
\hline $\mathrm{Y}$ & $\begin{array}{c}200 \\
2\end{array}$ & 1 & -2.002 & -4.80 & $\begin{array}{c}201 \\
1\end{array}$ & 1 & -2.402 & -4.42 & 2011 & 1 & -2.710 & -5.08 \\
\hline REN & $\begin{array}{c}200 \\
4\end{array}$ & 1 & -4.168 & -4.80 & $\begin{array}{c}199 \\
8\end{array}$ & 1 & -2.423 & -4.42 & 2004 & 1 & -3.658 & -5.08 \\
\hline LAB & $\begin{array}{c}200 \\
1\end{array}$ & 2 & -6.913 & -4.80 & $\begin{array}{c}199 \\
8\end{array}$ & 2 & -5.153 & -4.42 & 1997 & 2 & -5.516 & -5.08 \\
\hline CAP & $\begin{array}{c}200 \\
0\end{array}$ & 0 & -3.628 & -4.80 & $\begin{array}{c}201 \\
1\end{array}$ & 0 & -2.568 & -4.42 & 2000 & 0 & -3.169 & -5.08 \\
\hline
\end{tabular}

Note: $\mathrm{Y}=$ Economic growth measured by the real GDP; REN = Total energy consumption from all renewable resources; $\mathrm{LAB}=$ Labor force; $\mathrm{CAP}=$ Gross fixed capital formation.

Source: Authors' computation

In Table 2, the Clemente et al. (1998) unit root test result is showed out. To implement the test, we rely on both additive outliers and innovational outliers models. The results exhibit that all the variables have a unit root. Indeed, the t-statistic is smaller in absolute values than the 5\% critical value. Moreover, additional break dates have been found for the test. A brief discussion can be conducted with respect to some of the break dates found. For the real GDP variable, the following break dates are found by the tests: 1993, 1997, 2002, 2009, 2010 and 2011. The dates 2002 and 2011 both correspond to crisis episodes encountered by Côte d'Ivoire. September 2002 corresponds to the beginning of the politico-military crisis while in 2010-2011, there was a post-election crisis. The break in 2011 for the capital variable is undoubtedly due to the post-election crisis of 2010-2011 which saw the destruction of several existing infrastructures as well as a decline in investments.

Table 2: Clemente et al.'s (1998) unit root test results

\begin{tabular}{ccccccccc}
\hline \multirow{2}{*}{$\begin{array}{c}\text { Variable } \\
\mathrm{s}\end{array}$} & \multicolumn{3}{c}{ Additive outliers } & \multicolumn{3}{c}{ Innovative outliers } \\
\cline { 2 - 11 } & $\begin{array}{c}\mathrm{t}- \\
\text { statistic }\end{array}$ & value & $\begin{array}{c}\text { Break Date } \\
\text { valical }\end{array}$ & $\begin{array}{c}\text { Brea } \\
\mathrm{k}\end{array}$ & $\begin{array}{c}\mathrm{t}- \\
\text { Date } \\
\text { statistic } \\
\text { value }\end{array}$ & $\begin{array}{c}\text { Break Date } \\
1\end{array}$ & $\begin{array}{c}\text { Brea } \\
\mathrm{k} \\
\text { Date } \\
2\end{array}$ \\
\hline $\mathrm{Y}$ & -4.440 & -5.490 & 1997 & 2011 & -1.483 & -5.490 & 1993 & 2010 \\
\hline REN & -3.679 & -5.490 & 2001 & 2007 & -1.714 & -5.490 & 2002 & 2009 \\
\hline LAB & -3.084 & -5.490 & 1997 & 2008 & -2.969 & -5.490 & 2004 & 2009 \\
\hline CAP & -4.355 & -5.490 & 2001 & 2009 & -3.318 & -5.490 & 1998 & 2009 \\
\hline
\end{tabular}

Note: $\mathrm{Y}=$ Economic growth measured by the real GDP; REN = Total energy consumption from all renewable resources; $\mathrm{LAB}=$ Labor force; $\mathrm{CAP}=$ Gross fixed capital formation.

Source: Authors' computation

4.2. Cointegration and short and long-run estimates

Table 3 reports the bound testing for cointegration result. As it can be seen, it is indicated that the F-statistic is greater that the upper bound. Hence, there is enough statistical evidence against the null hypothesis of no cointegration. We conclude for a long-run relationship between renewable energy consumption, economic growth, capital and labor. Having found a cointegration relationship, the next step is to estimate the ARDL-ECM which results are presented in Table 4.

Table 3: ARDL bound test result for cointegration

\begin{tabular}{cccc}
\hline Number of covariates & F-statistic & \multicolumn{2}{c}{ Critical value at the level of significance 5\% } \\
\cline { 3 - 4 } & & Lower Bound & Upper Bound \\
\hline 3 & 4.496 & 2.79 & 3.67 \\
\hline
\end{tabular}

Source: Authors' computation 
Results from Table 4 suggests that the one period lagged-value of the error correction term is negative and statistically significant at the 1\% significance threshold. This further supports the cointegration relationship and confirms the presence of a long-run and stable relationship between the series. As a remainder, all the variables are transformed into the natural logarithm. Thus, the obtained coefficients can be interpreted as elasticities. In the long run, renewable energy consumption has a negative but non-significant impact on economic growth in Côte d'Ivoire. This result is similar to Ohlan (2016) who reported an absence of impact of renewable energy on economic growth in India in the long run. We explain the absence of impact of renewable energy consumption on economic growth by three main reasons which are interrelated. First, the current level of renewable energy in the total energy mix of Côte d'Ivoire is low. Second, the growth-driven sectors do not yet use renewable energies in a way that can impulse economic growth. Third, investments and actions in the renewable energy sector are growing but remain low.

In the short run, the relationship is mixed. In the first period, a $1 \%$ increase in renewable energy consumption increases real GDP by $0.085 \%$ (Table 4 ). Nevertheless, this effect is weak since the associated coefficient is significant at $10 \%$. In the second period, the effect of renewable energy consumption on economic growth is negative and significant at the 5\% level. A computation of the short-run overall effect $(-0.093+0.085=-0.008)$ show that the impact of renewable energy consumption on economic growth is a negative and very weak one. The mixed short-run effects (positive and negative) suggest that the transition between non-renewable energy and renewable energy is not effective but is ongoing. In fact, the transition would have been effective if the short-run coefficients were positive and statistically significant. Moreover, the mixed result could be associated with the fact that energy production from renewable sources has a great variability from year to year. Hence, the effect is not constant throughout the time. To comfort this explanation, we compute the coefficient of variation $(\mathrm{CV})$ of all the variables under study. The results show that the renewable energy consumption variable has the greatest value for this indicator, $30.4 \%$ (the CV for the real GDP, labor force and capital are respectively: $16.9 \%, 12.6 \%$ and $26.5 \%$ ).

Regarding the control variables, in the long run, economic growth is positively and significantly affected by both capital and labor. Specifically, a $1 \%$ increase in capital raises GDP by $0.379 \%$ and a $1 \%$ increase in labor force raises GDP by $1.289 \%$. This shows that capital and labor play a great role in the renewable energy-economic growth nexus. The short-run estimates also reveal positive impacts of capital and labor on economic growth. In short-run, a $1 \%$ increase in capital and labor leads to a raise of $0.173 \%$ and $0.549 \%$ on economic growth respectively.

Diagnostic tests presented in Table 4 show that the ARDL model is valid since there is no serial correlation and no heteroscedasticity in the residuals of the model. Furthermore, the residuals are normal and the functional form test shows that the model does not suffer of any mis-specification. The ARDL model is also stable since, as depicts in Fig.1, the cumulative sum of recursive residuals (CUSUM) and the cumulative sum of the square of recursive residuals (CUSUMSQ) statistics are within the confidence boundaries (Browns et al., 1975; Pesaran et al., 2001). Thus, the estimated coefficients are stable throughout time.

Table 4: ARDL $(1,2,0,0)$ estimation result

\begin{tabular}{|c|c|c|c|}
\hline \multicolumn{4}{|l|}{ Dependent variable : Real GDP (Y) } \\
\hline Co-variables & Coefficient & Standards Errors & P-Value \\
\hline \multicolumn{4}{|l|}{ Short-run estimates } \\
\hline$\Delta \mathbf{R E N}_{\mathrm{t}}$ & $-0.093 * *$ & 0.039 & 0.031 \\
\hline$\Delta \mathbf{R E N}_{\mathrm{t}-1}$ & $0.085^{*}$ & 0.049 & 0.100 \\
\hline$\Delta \mathbf{C A P}$ & $0.173 * * *$ & 0.021 & 0.000 \\
\hline$\Delta \mathbf{L A B} \mathbf{B}_{\mathbf{t}}$ & $0.549 * *$ & 0.205 & 0.017 \\
\hline \multicolumn{4}{|l|}{ Long-run estimates } \\
\hline $\mathbf{R E N}_{\mathrm{t}}$ & -0.064 & 0.108 & 0.566 \\
\hline $\mathbf{C A P}_{\mathbf{t}}$ & $0.379 * * *$ & 0.098 & 0.001 \\
\hline $\mathbf{L A B} \mathbf{B}_{\mathbf{t}}$ & $1.289 * * *$ & 0.268 & 0.000 \\
\hline Constant & 3.507 & 2.962 & 0.254 \\
\hline $\mathbf{E C M}_{t-1}$ & $-0.385 * * *$ & 0.059 & 0.000 \\
\hline Diagnostic tests & Statistic & P-Value & \\
\hline Jarque Bera Normality test & 0.337 & 0.845 & \\
\hline Breusch - Godfrey Serial Correlation LM test & 1.456 & 0.266 & \\
\hline Breusch-Pagan-Godfrey Heteroskedasticity test & 1.863 & 0.149 & \\
\hline Ramsey Reset specification test & 3.234 & 0.092 & \\
\hline
\end{tabular}

Note: $* * *, * * *$ denotes significance at $10 \%, 5 \%$ and $1 \%$ respectively. Note: $\mathrm{Y}=$ Economic growth measured by the real GDP; REN $=$ Total energy consumption from all renewable resources; $\mathrm{LAB}=$ Labor force; $\mathrm{CAP}=\mathrm{Gross}$ fixed capital formation. ECT= Error correction term. The maximum lag for the dependent variable is set to 3 and 
to 2 for the other regressors. The ARDL optimal lag is selected based on the Akaike Information Criterion. Source: Authors' computation

Having estimated the long-run effect of renewable energy consumption on economic growth through the ARDL framework, we test the robustness of this relationship by conducting new set of estimates based on the Fully Modified Ordinary Least Squares (FMOLS) and the Dynamic Ordinary Least Squares (DOLS) methods. Both approaches provide not only consistent estimation of the cointegrated vector but also correct potential endogeneity and serial correlations. The results, reported in Table 5 show that regardless the model used, the nonsignificant negative effect of renewable energy consumption on economic growth still hold. Thus, the estimated relationship is robust and reliable. Concerning the capital and labor variables, the positive effects estimated using the ARDL model are still valid when DOLS and FMOLS are used, with the impact of labor greater than the one of capital.

Table 5: Long-run estimates from ARDL, DOLS and FMOLS

Dependent variable : Real GDP (Y)

\begin{tabular}{lllllll}
\hline & \multicolumn{2}{c}{ ARDL } & \multicolumn{3}{c}{ DOLS } & FMOLS \\
\hline Co-variables & Coefficient & $\begin{array}{l}\text { Standard } \\
\text { Errors }\end{array}$ & Coefficient & $\begin{array}{l}\text { Standard } \\
\text { Errors }\end{array}$ & Coefficient & $\begin{array}{l}\text { Standard } \\
\text { Errors }\end{array}$ \\
\hline REN $_{\mathbf{t}}$ & -0.064 & 0.108 & -0.087 & 0.193 & -0.047 & 0.075 \\
CAP $_{\mathbf{t}}$ & $0.379^{* * *}$ & 0.098 & $0.200^{*}$ & 0.104 & $0.195^{* * *}$ & 0.037 \\
LAB $_{\mathbf{t}}$ & $1.289^{* * *}$ & 0.268 & $1.309^{* *}$ & 0.569 & $1.155^{* * *}$ & 0.187 \\
Constant & 3.507 & 2.962 & 3.877 & 6.636 & 5.849 & 2.122 \\
\hline
\end{tabular}

Note: $* * *, * * *$ denotes significance at $10 \%, 5 \%$ and $1 \%$ respectively. Note: $\mathrm{Y}=$ Economic growth measured by the real GDP; REN $=$ Total energy consumption from all renewable resources; $\mathrm{LAB}=$ Labor force; $\mathrm{CAP}=\mathrm{Gross}$ fixed capital formation.

Source: Authors' computation

Fig. 1: CUSUM and CUSUM Squares Stability test
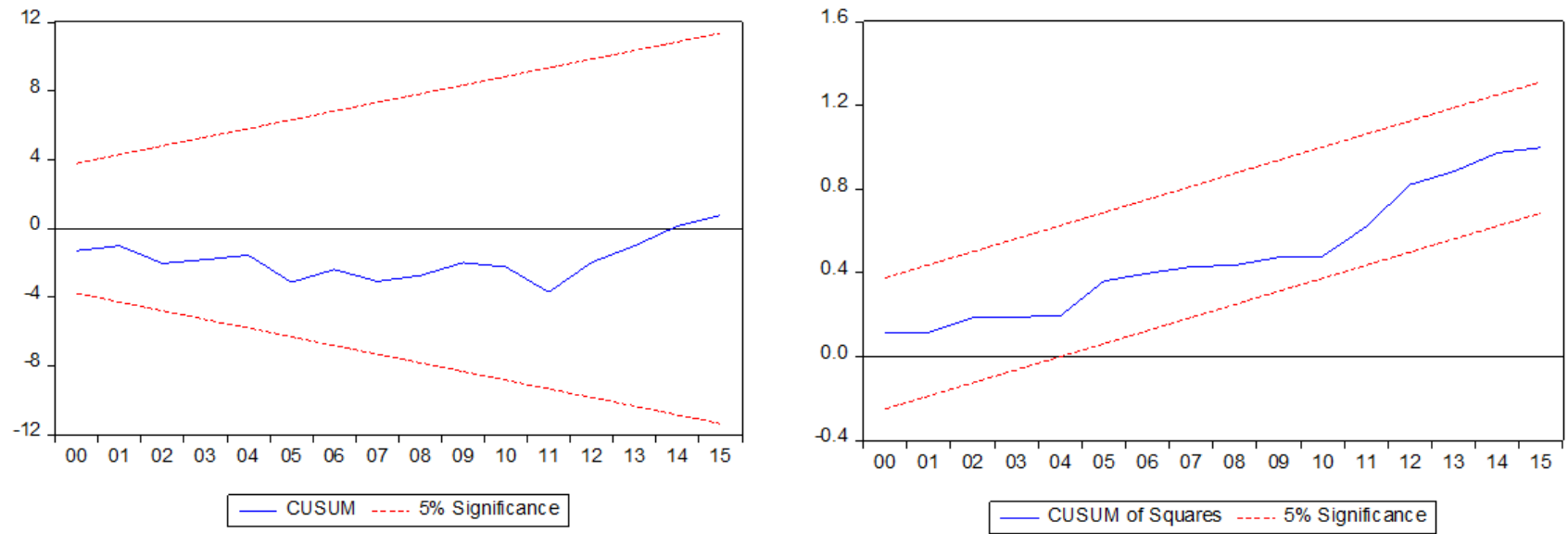

Source: Authors' computation

\section{Conclusion and policy recommendations}

Using annual data from 1991 to 2015 for Côte d'Ivoire, this study undertook an analysis of the dynamic impact of renewable energy consumption on economic growth. The paper uses a neoclassical production function that includes capital and labor. We apply the ARDL approach of Pesaran et al. (2001) which offers a suitable framework for a dynamic analysis. In an attempt of obtaining unbiased results, additional methods have been used namely: the FMOLS and the DOLS. The results that emanate from the study is that in the short run, renewable energy consumption has a mixed impact on economic growth while in the long-run, the impact on economic growth is not significant. The mixed short-run effect seems to support that the transition between non-renewable energy and renewable energy is not yet effective but is under way. The absence of long-run effect could be due to three main reasons namely: the low current level of renewable energy in the total energy mix, the low usage of renewable energy in the key sectors of the economy and the low (but growing) investments in the renewable energy sector.

Based on these results, additional investments need to be made in the renewable energy sector. The deployment process of renewable energy should be emphasized in the short run so that investment can be sustainable in the long run. First, this would increase the export capacity of Côte d'Ivoire (Net electricity exports 
stand at $849 \mathrm{GWh}$ in 2015) as well as its ability to meet the increasing energy domestic demand. Second, this will allow to increase energy security. The country could consider the implementation of infrastructure projects aiming at the construction of solar parks. Regarding this, the northern region of Côte d'Ivoire could be a favorable destination of these solar parks as it has the greatest degree of solar radiation. Once this is done, interconnection grids can be constructed for the purpose of conveying renewable based-energy to other regions within the country. The same approach may also work for wind-based energy. This will allow to have a country that is fully integrated across sub-national regions at the energy level. Furthermore, policies aiming at promoting the benefits of using renewable energy sources especially at the household and rural levels as well as in the agriculture sector should be implemented. This calls for an energetic transition which starts from the microeconomic level. Hence, policy makers could establish financing mechanisms for small renewable energy projects at the national level through micro-credits. Moreover, with the specific view on solar, the current value added tax of $9 \%$ on imports of solar equipment should be removed, allowing for more promotion of solar technologies within the poor Ivoirian population. Future researches may investigate the effect of renewable energy across sectors in Côte d'Ivoire.

\section{References}

Alper, A., Oguz, O. (2016). The role of renewable energy consumption in economic growth: Evidence from asymmetric causality. Renewable and Sustainable Energy Reviews, 60, 953-959.

Amri, F. (2017). The relationship amongst energy consumption (renewable and nonrenewable), and GDP in Algeria. Renewable and Sustainable Energy Reviews, 76, 62-71.

Apergis, N., Payne, J. E. (2011). On the causal dynamics between renewable and non-renewable energy consumption and economic growth in developed and developing countries. Energy Syst, 2, 299-312.

Aslan, A. (2016). The causal relationship between biomass energy use and economic growth in the United States. Renewable and Sustainable Energy Reviews, 57, 362-366.

Bhattacharya, M., Paramati, S. R., Ozturk, I., Bhattacharya, S. (2016). The effect of renewable energy consumption on economic growth: Evidence from top 38 countries. Applied Energy, 162, 733-741.

Bildirici, M., Özaksoy, F. (2016). Woody Biomass Energy Consumption and Economic Growth in Sub-Saharan Africa. Procedia Economics and Finance, 38, 287 - 293.

Browns, R., Durbin, J., Ewans, J. (1975). Techniques for testing the constancy of regression relations overtime. $J$. R. Stat. Soc, 37, 149-172.

Clemente, J., Montanes, A., Reyes, M. (1998). Testing for a unit root in variables with a double change in the mean. Economics Letters, 59, 175-182.

da Silva, P. P., Cerqueira, P. A., Ogbe, W. (2018). Determinants of renewable energy growth in Sub-Saharan Africa: Evidence from panel ARDL. Energy, 156, 45-54.

Esso, L. J. (2010). Threshold cointegration and causality relationship between energy use and growth in seven African countries. Energy Economics, 32, 1383-1391.

Esso, L. J., Keho, Y. (2016). Energy consumption, economic growth and carbon emissions: Cointegration and causality evidence from selected African countries. Energy, 114, 492-497.

Hermann, S., Miketa, A., Fichaux, N. (2014). Estimating the Renewable Energy Potential in Africa. IRENA-KTH working paper. International Renewable Energy Agency, Abu Dhabi.

Johansen, S. (1988). Statistical analysis of cointegration vectors. J Econ Dyn Control, 231-254.

Johansen, S., Juselius, K. (1990). Maximum likelihood estimation and inferences on cointegration with. Oxford Bull Econ Stat, 52, 169-210.

Keho, Y. (2007). Causal relationship between energy consumption and GDP: an empirical analysis for five West African countries. The Journal of Energy and Development, 33(1), 23-32.

Koua, B. K., Koffi, P. M., Gbaha, P., Touré, S. (2015). Present status and overview of potential of renewable energy in Cote d'Ivoire. Renewable and Sustainable Energy Reviews, 41, 907-914.

Kouakou, A. K. (2011). Economic growth and electricity consumption in Cote d'Ivoire: Evidence from time series analysis. Energy Policy, 39, 3638-3644.

Lean, H., Smyth, R. (2010). On the dynamics of aggregate output, electricity consumption and exports in Malaysia: evidence from multivariate Granger causality tests. Appl Energy, 87(6), 1963-71.

Ocal, O., Aslan, A. (2013). Renewable energy consumption-economic growth nexus in Turkey. Renewable and Sustainable Energy Reviews, 28, 494-499.

Ohlan, R. (2016). Renewable and nonrenewable energy consumption and economic growth in India. Energy Sources, Part B: Economics, Planning, and Policy, 11(11), 1050-1054.

Pesaran, M. H., Shin, Y., Smith, R. J. (2001). Bounds testing approaches to the analysis of level relationships. Journal of applied econometrics, 16(3), 289-326.

Pesaran, M., Shin, Y. (1999). An autoregressive distributed lag modeling approach to cointegration analysis. In: Strom S, editor. Chapter 11 in econometrics and economic theory in the 20th century: the Ragnar Frisch 
Centennial symposium. Cambridge: Cambridge University Press.

Shahbaz, M., Loganathan, N., Zeshan, M., Zaman, K. (2015). Does renewable energy consumption add in economic growth? An application of auto-regressive distributed lag model in Pakistan. Renewable and Sustainable Energy Reviews, 44, 576-585.

Solarin, S. A., Ozturk, I. (2015). On the causal dynamics between hydroelectricity consumption and economic growth in Latin America countries. Renewable and Sustainable Energy Reviews, 52, 1857-1868.

Yazdi, S. K., Shakouri, B. (2017). Renewable energy, nonrenewable energy consumption, and economic growth. Energy Sources, Part B: Economics, Planning, and Policy, 1038-1045.

Zivot, E., Andrews, D. (1992). Further evidence on the great crash, the oil-price shock, and the unit-root hypothesis. J. Bus. Econ. Stat, 10(3), 251-270. 